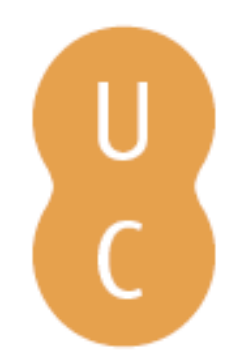

\title{
nombalina
}

\section{"As dinâmicas europeias, entre os Estados, as redes e os atores multiterritoriais": uma visão desde a Ciência Jurídica}

\author{
Autor(es): $\quad$ Aragão, Alexandra \\ Publicado por: Imprensa da Universidade de Coimbra \\ URL \\ persistente: URI:http://hdl.handle.net/10316.2/47307 \\ DOI: $\quad$ DOI:https://doi.org/10.14195/978-989-26-1849-4_16 \\ Accessed : $\quad$ 26-Apr-2023 10:35:47
}

A navegação consulta e descarregamento dos títulos inseridos nas Bibliotecas Digitais UC Digitalis, UC Pombalina e UC Impactum, pressupõem a aceitação plena e sem reservas dos Termos e Condições de Uso destas Bibliotecas Digitais, disponíveis em https://digitalis.uc.pt/pt-pt/termos.

Conforme exposto nos referidos Termos e Condições de Uso, o descarregamento de títulos de acesso restrito requer uma licença válida de autorização devendo o utilizador aceder ao(s) documento(s) a partir de um endereço de IP da instituição detentora da supramencionada licença.

Ao utilizador é apenas permitido o descarregamento para uso pessoal, pelo que o emprego do(s) título(s) descarregado(s) para outro fim, designadamente comercial, carece de autorização do respetivo autor ou editor da obra.

Na medida em que todas as obras da UC Digitalis se encontram protegidas pelo Código do Direito de Autor e Direitos Conexos e demais legislação aplicável, toda a cópia, parcial ou total, deste documento, nos casos em que é legalmente admitida, deverá conter ou fazer-se acompanhar por este aviso.

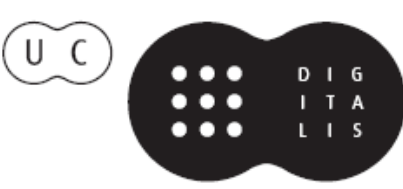


Euro-Atlântico:

Espaço de Diálogos

Isabel Maria Freitas Valente

Iranilson Buriti de Oliveira

(Coord)

\section{VISÕES \\ INTERDISCIPLINARES \\ DA EUROPA \\ E DO MUNDO:}

uma experiência de convergência

disciplinar em homenagem a

Maria Manuela Tavares Ribeiro

Alexandra Aragão

Isabel Maria Freitas Valente

Dulce Lopes

(org.)

Editora da Universidade Federal de Campina Grande

Imprensa da Universidade de Coimbra

2019 


\section{“AS DINÂMICAS EUROPEIAS, ENTRE OS ESTADOS, AS REDES E OS ATORES MULTITERRITORIAIS", UMA VISÃO DESDE A CIÊNCIA JURÍdICA}

Alexandra Aragão

Uma visão jurídica sobre os temas abordados na desafiadora reflexão de João Luis Fernandes, a propósito dos efeitos de representações cartográficas "não realistas" e "tendenciosas" do objeto Europa, suscita inúmeras questões jurídicas cuja análise mais aprofundada poderia complementar uma compreensão espacial e crítica da Europa, enquanto construção jurídico-política.

Destacamos algumas:

- A ideia de estados enquanto "entidades bem delimitadas" poderia ser objeto de análise jurídica a partir do caso de estudo de Gibraltar, e do recente acórdão do Tribunal de Justiça da União Europeia ${ }^{1}$ que declara, em sede de reenvio prejudicial solicitado pelo Supremo Tribunal de Gibraltar, que a Diretiva europeia relativa ao controlo da aquisição e da detenção de $\operatorname{armas}^{2}$ não se aplica no território de Gibraltar, espaço este, de resto, não incluído no território aduaneiro da União Europeia nos termos do Ato de Adesão de 1972, pelo qual do Reino da Dinamarca, da Irlanda e do Reino Unido da Grã Bretanha e da Irlanda do Norte passaram a pertencer às Comunidades Europeias.

- A "paleta colorida" que é o mapa político da Europa, poderia ser confrontado com outras representações cartográficas com relevância jurídico-ambiental, como sejam as regiões biogeográficas, que, nos

1 Acórdão do Tribunal de Justiça (Grande Secção) de 23 de janeiro de 2018. Albert Buhagiar e o. contra Minister for Justice.

2 Diretiva 91/477/CEE, de 18 de junho de 1991, alterada pela Diretiva 2008/51/ CE, de 21 de maio de 2008. 
termos da Diretiva Habitats ${ }^{3}$, mostram uma Europa mais natural cujas fronteiras delimitam não 28 mas sete grandes espaços, correspondentes às sete regiões biogeográficas alpina, atlântica, boreal, continental, macaronésica, mediterrânica e panónica ${ }^{4}$, dentro dos quais de desenvolvem os habitats naturais e as espécies que constituem, nas palavras nas Instituições Europeias, "património comum dos povos europeus"s.

- A maior ou menor "dificuldade de comunicação e circulação de pessoas e mercadorias" nas penínsulas, de relevo acidentado, da Europa mediterrânica, pode ser analisada, a partir do Direito, em relação à política de coesão territorial, nascida com o Tratado de Lisboa e tendo como objetivo de "reduzir a disparidade entre os níveis de desenvolvimento das diversas regiões e o atraso das regiões menos favorecidas", analisada no Relatório da Comissão ao Parlamento Europeu, ao Conselho, ao Comité Económico e Social Europeu e ao Comité das Regiões "A minha Região, a minha Europa, o nosso futuro: sétimo relatório sobre a coesão económica, social e territorial"7.

- Outros temas, mais óbvios mas não menos complexos, que suscitam análises cruzadas entre a geografia e o direito são as questões da cidadania europeia e dos direitos dos cidadãos da $\mathrm{UE}^{8}$, para uma leitura jurídica do que pode significar aquilo a que o autor chama o cidadão "orientar-se pelo passaporte e pelo cartão cidadão"; do direito europeu de asilo e emigração baseado na solidariedade entre Estados-

3 Diretiva 92/43/CEE, de 21 de maio de 1992 relativa à preservação dos habitats naturais e da fauna e da flora selvagens.

${ }^{4}$ Artigo $1^{\circ}$ c) iii.

5 Por exemplo o parágrafo 7 do preâmbulo da Diretiva 2009/147/CE, de 30 de novembro de 2009 relativa à conservação das aves selvagens.

${ }^{6}$ Artigo 174 §2 do Tratado sobre o Funcionamento da União Europeia.

$7 \operatorname{COM}(2017) 583$ final, Bruxelas, 9.10.2017.

${ }^{8}$ Artigo 20 e seguintes do Tratado sobre o Funcionamento da União Europeia e muito particularmente o novo direito de desencadear iniciativas de cidadania, previsto no artigo 11 do Tratado da União Europeia e no Regulamento (UE) $n^{\circ}$ 211/2011 de 16 de fevereiro de 2011, cujo exercício tem contribuído para o envolvimento direto dos cidadãos no processo de construção europeia, como demonstram as iniciativas em curso, disponíveis em http://ec.europa.eu/citizens-initiative/public/?lg=pt. 
Membros e na relação equitativa aos nacionais de países terceiros ${ }^{9}$, a propósito da visão da Europa como "vértice de múltiplas diásporas que aqui se procuram reterritorializar"; e do direito europeu em matéria de terrorismo e criminalidade organizada, para desenvolver o estudo da atuação dos "atores informais da criminalidade e do terrorismo", domínios de "criminalidade particularmente grave com dimensão transfronteiriça" 10 , nos quais a assunção de competências pela União Europeia, através da Europol ${ }^{11}$ e do Eurojust ${ }^{12}$, parece ser a reação mais lógica.

\footnotetext{
${ }^{9}$ A política comum em matéria de asilo, imigração e controlo das fronteiras externas da União Europeia está prevista no artigo 67 do Tratado sobre o Funcionamento da União Europeia e tem como face visível a vigilância das fronteiras marítimas externas, coordenada pela Agência Europeia de Gestão da Cooperação Operacional nas Fronteiras Externas dos Estados-Membros da União Europeia (Frontex), (Regulamento (UE) $\mathrm{n}^{\circ}$ 656/2014, de 15 de maio de 2014).

${ }^{10}$ Nos termos do artigo 83 do Tratado sobre o Funcionamento da União Europeia.

11 Regulamento (UE) 2016/794, de 11 de maio de 2016, que cria a Agência da União Europeia para a Cooperação Policial (Europol).

12 Decisão do Conselho 2002/187/JAI de 28 de Fevereiro de 2002 relativa à criação da Eurojust a fim de reforçar a luta contra as formas graves de criminalidade, alterada sucessivamente em 2003 e em 2009.
} 